\title{
Grasses of the Isalo National Park, Madagascar - checklist, origins, and significance
}

\author{
Nantenaina Herizo Rakotomalala,,", Mihajamalala \\ Andotiana Andriamanohera", David Rabehevitra", \\ Cédrique Lova Solofondranohatral,", Vololoniaina Hary \\ Jeannodal, Andriantsitohaina Ranaivojaonal', Hélène \\ Ralimanana", Maria Sergeevna Vorontsovalv
}

\author{
Correspondence: \\ Nantenaina Herizo Rakotomalala \\ Département de Biologie et Écologie Végétales, Faculté des \\ Sciences, Université d'Antananarivo, PO Box 906, Antananarivo 101, \\ Madagascar \\ Email: nantenaina.herizo5@gmail.com / n.rakotomalala@kew.org
}

\begin{abstract}
Grasses are one of the best documented plant families worldwide in terms of taxonomy, but they are still poorly known in Madagascar. Our understanding of their diversity remains incomplete since grasses and grasslands are assumed by many to be weeds and degraded wastelands. This project aimed to list the grasses in Isalo National Park (NP) in order to understand their diversity and endemicity, as well as the history of Isalo's grasslands. Examination of herbarium specimens and new field inventories allowed us to confirm 589 records of grass occurrences in our study area. They were assigned to 112 species, of which 38 species are new records for Isalo NP. The Isalo grass flora includes seven of the eleven Poaceae subfamilies present in Madagascar and is particularly rich in Panicoideae, which make up $65 \%$ of the species. Nearly $22 \%$ of the grass species of Isalo are endemic to Madagascar, of which three species and one variety are restricted to Isalo massif, including two unusual ground cover species Tristachya humbertii A.Camus and Tristachya [Isalus isalensis]. open grasslands harbour the highest diversity of grass species, followed closely by riparian forests. The history of the management of Isalo NP by the Bara people, as well as the endemism and the native origin of its grasses and other species are consistent with an ancient origin of Isalo's ecosystems. We urge that the conservation of Isalo's grassy ecosystems, as well as that of the plants and animals that inhabit them be prioritized.
\end{abstract}

\section{RÉSUMÉ}

Les graminées sont parmi les familles de plantes les mieux documentées au niveau mondial en termes de taxonomie, mais sont encore mal connues à Madagascar. Notre compréhension de leur diversité reste incomplète, vu que les graminées et les savanes sont considérées par beaucoup comme des mauvaises herbes et des friches dégradées. Ce projet visait à établir une liste des graminées connues du Parc National (PN) de I'Isalo, afin de comprendre leur diversité et leur endémicité, ainsi que I'histoire des écosystèmes herbeux de l'Isalo. L'examen des spécimens d'herbiers et les nouveaux inventaires sur terrains nous ont permis de générer 589 occurrences de graminées de notre site d'étude. Elles ont été attribuées à 112 espèces de Poaceae, dont 38 sont de nouvelles collectes pour le massif de I'Isalo. La flore herbacée du massif de I'Isalo comprend sept des onze sous-familles de Poaceae présentes à Madagascar et est particulièrement riche en Panicoideae qui représentent $65 \%$ des espèces. Près de $22 \%$ des espèces de graminées de I'Isalo sont endémiques de Madagascar, dont trois espèces et une variété sont restreintes à Isalo, y compris les deux espèces de plantes couvre-sols inhabituelles Tristachya humbertii A.Camus et Tristachya [Isalus isalensis]. Les prairies ouvertes abritent la plus grande diversité d'espèces de graminées, suivies de près par les forêts ripicoles. L'histoire de la gestion du PN de I'Isalo par les habitants de la région du groupe Bara, ainsi que l'endémisme et l'origine autochtone de ses graminées et autres espèces sont cohérents avec une origine ancienne des écosystèmes de l'Isalo. Nous préconisons instamment que la conservation de ces prairies et savanes de I'Isalo, ainsi que les plantes et les animaux qui les habitent soit priorisée.

\section{INTRODUCTION}

Grasses (plant family Poaceae) are one of the most diverse and widespread plant families and are comparatively well known in the world (Kellogg 2015). They diversified throughout the Cenozoic in India, northern Africa and South America (Bouchenak-Khelladi et al. 2010, Strömberg 2011). They now represent the 5th largest angiosperm family with ca. 12000 species and are distributed on all continents (Convey 2001, Bouchenak-Khelladi et al. 2010, Soreng et al. 2017, Vorontsova et al. 2021). Linnean Poaceae classification systems were first developed in the 18th century, once based on morphological treatments, and then continuously updated using molecular data (Grass Phylogeny Working Group or GPWP 2001, Kellogg 2015, soreng et al. 2015). For many parts of the world, comprehensive grass floras have been published over the last 30

\footnotetext{
I Département de Biologie et Écologie Végétales, Faculté des Sciences, Université d'Antananarivo, PO Box 906, Antananarivo 101, Madagascar II Kew Madagascar Conservation Centre, II J 131 B, Ambodivoanjo, Ivandry, Antananarivo 101, Madagascar

III Madagascar National Parks, Isalo, Ranohira, Ihorombe, Madagascar

IV Comparative Plant and Fungal Biology, Royal Botanic Gardens, Kew, Richmond, Surrey TW9 3AB, UK

Citation Rakotomalala, N. H, Andriamanohera, M. A., Rabehevitra, D., Solofondranohatra, C. L., Jeannoda, V. H., Ranaivojaona, A., Ralimanana, H., Vorontsova, M. S. 2021. Grasses of the Isalo National Park, Madagascar - checklist, origins, and significance. Madagascar Conservation \& Development 16, 1: 14-24.
} http://dx.doi.org/10.4314/mcd.v16i1.1 


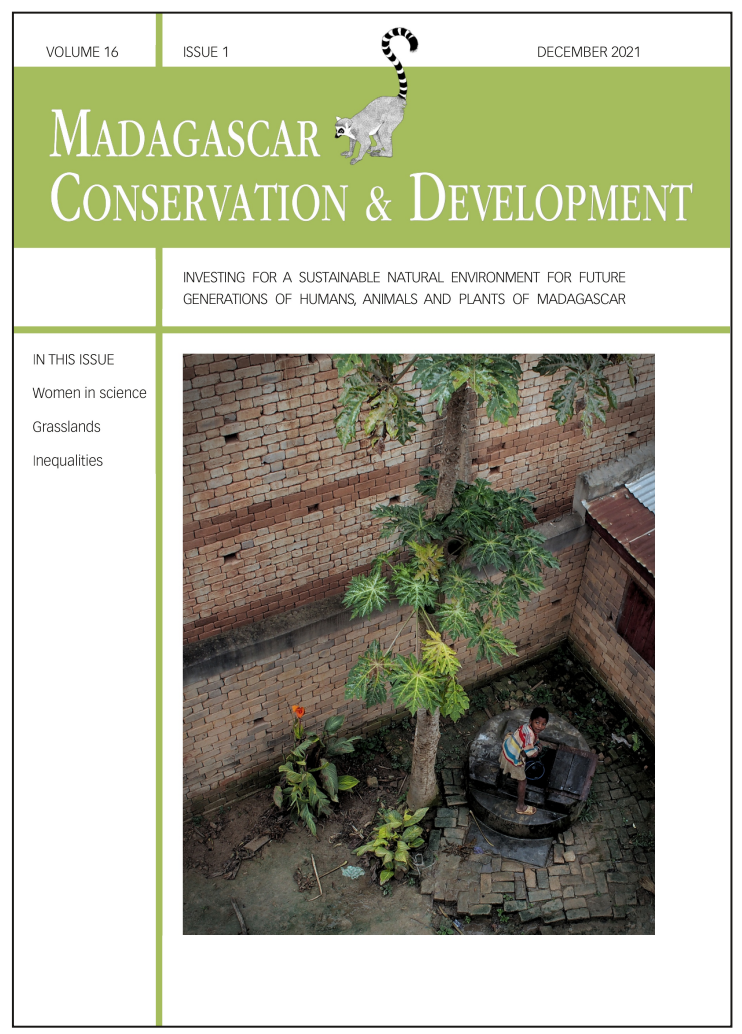

Madagascar Conservation \& Development is the journal of Indian Ocean e-Ink. It is produced under the responsibility of this institution. The views expressed in contributions to MCD are solely those of the authors and not those of the journal editors or the publisher.

All the Issues and articles are freely available at https://www.journalmcd.com

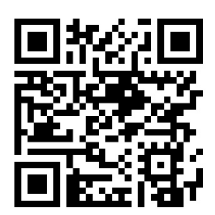

Contact Journal MCD

info@journalmcd.net for general inquiries regarding MCD funding@journalmcd.net to support the journal

Madagascar Conservation \& Development Institute and Museum of Anthropology

University of Zurich

Winterthurerstrasse 190

CH-8057 Zurich

Switzerland

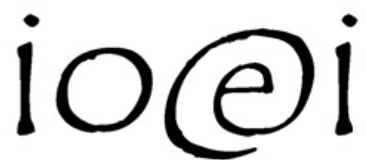

Indian Ocean e-Ink

Promoting African Publishing and Education

www.ioeink.com

Missouri Botanical Garden (MBG)

Madagascar Research and Conservation Program

敨 Missouri Botanical Garden BP3391

Antananarivo, 101, Madagascar 
years (e.g., Davidse et al. 1994, Barkworth et al. 2003, Barkworth et al. 2007).

Unlike the rest of the world, Malagasy science still overlooks grasses as they are often considered to be weeds and cattle feed not requiring study. Consequently, the data we have about them remains incomplete and outdated. A single book has long been the only reference source for the grasses in Madagascar: Graminées des pâturages et des cultures à Madagascar by Jean Bosser (1969), even though it covers only around a half of the grass species in Madagascar. Taxonomic studies of Malagasy grasses, which were largely made by Aimée Camus, as well as most collection of specimens, pre-date 1970 (Vorontsova et al. 2018). Moreover, a significant number of the species held in the main herbaria of Tsimbazaza, Antananarivo (TAN) and of Muséum National d'Histoire Naturelle Paris (P), are represented by just a single specimen, or remain unidentified. Yet, many of them potentially represent new taxa to science and remain undescribed (Rabarivola et al. 2019a-c; for a full analysis see Vorontsova et al. 2021). However, grasses and grasslands are omnipresent in Madagascar and in Malagasy people's lives, as the source of daily rice and cattle forage, and forming extensive grassy vegetation types.

In Madagascar, grasslands occupy ca. $65 \%$ of the island's surface, while 70 to $80 \%$ of the primary forests would have been lost due to human activities (Du Puy \& Moat 1996, Moat and Smith 2007, Vieilledent et al. 2018). The assumption that Madagascar was once entirely covered by forests has led to the belief that grassy ecosystems are degraded wastelands. Scientific debates on the real origin of these ecosystems in Madagascar continue to date. Previous research showed that some endemic grass lineages already evolved on the island millions of years before human settlement and that some pollen and charcoal deposits are pre-human, which indicates open habitats with natural fires (Burney 1987, 1997, Gasse and Van Campo 1998, Hackel et al. 2018). Recently, highland grassy assemblages confirm the existence of fire and herbivory disturbance regimes before human settlement (Solofondranohatra et al. 2020). Moreover, ancient diversity and endemicity of many plants and animals in grasslands have been recognized (Bond et al. 2008, Vorontsova et al. 2016). These discoveries tend to gradually highlight the presence of grassy ecosystem before the arrival of people on the island. Currently, the distinction between secondary and ancient grasslands remains more at the heart of the debate, which shall involves multidisciplinary and even more complex studies.

Grasses represent the 4th largest plant family in Madagascar with 541 recognized species and an estimated 40\% endemicity (Vorontsova et al. 2016). Following the recent progress in documenting grass diversity in Madagascar, the grass family is expected to be more diverse than what we currently know. New species are still being described and new records are being made following new botanical surveys and re-examination of specimens held in herbaria (Vorontsova and Rakotoarisoa 2014, Vorontsova et al. 2015).

This study documents the grass diversity within the Isalo National Park (NP). We establish a list of species, build grass diversity knowledge among the protected area employees, evaluate the diversity and endemicity of grasses and discuss the origin of Isalo's grasslands using data on the historical use, and the flora and fauna of the Isalo's grassland. In this paper we use the term "grassland" to denote grass-dominated open canopy ecosystems with few or no trees to standardize our terminology to Gautier et al. (2018), and we use the term "tapia" for tapia grassland (find Solofondranohatra et al. 2018); these terms are merely used for consistency and do not imply any assumptions regarding their origins.

\section{STUDY SITE}

Isalo NP is one of the largest National Parks and one of the earliest protected areas in Madagascar. It was created in 1962 and covers an area of about 86579 ha, currently managed by the Madagascar National Parks (MNP) (MNP 2017). It is found in the southwestern corner of Fianarantsoa and belongs in general to the commune of Ranohira, District of Ihosy, Region of Ihorombe, Province of Fianarantsoa. However, a part of the park is included in the commune of llemby and Berenty, District of Ankazoabo, Region of Atsimo-Andrefana, Province of Toliara. Isalo NP is unique for its landscape made of plateau grassland interspersed by deep canyons (reaching $200 \mathrm{~m}$ deep), and natural geological sandstone outcrops that sometimes takes spectacular shapes (e.g., formations locally named-known as boot, queen, window).

Isalo NP is phytogeographically included in the central ecoregion and is part of the central Tapia (Uapaca bojeri Baill.) sclerophyllous woodlands, recently shown to be functionally a grassy ecosystem (Humbert 1955, Moat and Smith 2007, Solofondranohatra et al. 2018). About $40 \%$ of the park is covered by open grassland interspersed by fire-resistant trees. Tapia occurs in the northeast and the western third of the protected area, whereas riparian forest in the deeply carved canyons from the centre towards the east. A dwarf and xerophytic vegetation occurs in open rocky areas, whereas marsh and Pandanus thickets are found in humid ones (Gautier 2018). The climate is seasonal, mainly hot, and sub-humid (Koechlin et al. 1974). Temperatures range from monthly means of $17^{\circ} \mathrm{C}$ to $25^{\circ} \mathrm{C}$ (Swierkosz 2007) but may drop to $7.3^{\circ} \mathrm{C}$ during the cold season between June and August or may increase over $32^{\circ} \mathrm{C}$ during the hot season between December and February (Goodman et al. 2018, 1561-1575). Around 850 to $1200 \mathrm{~mm}$ of rain falls every year, with 90 to $93 \%$ falling between November and April (Swierkosz 2007), and permanent rivers, streams and seasonal watercourses cross the area.

Isalo NP is located in one of the least populated regions of the country, where the Bara group is dominant (INSTAT Madagascar 2020). These semi-nomadic zebu-herding people, once in search of grazing land, settled in Ranohira before the 19th century. They mainly used the current Isalo's spectacular sandstone cliffs for burials and open grasslands for grazing cattle (zebu), where fire is regularly set at least once a year to generate forage (Rajaofera 2007, Zafisoalizy 2011). Today grasslands continue to burn, and the Park is under additional pressures such as tourism, informal resources exploitation, wood clearing and species introduction in the park (Swierkosz 2007).

Isalo massif is dominated by grasslands, therefore providing a suitable site to understand grass diversity conserved in a protected system undisturbed by modern agriculture (MNP 2017, Goodman et al. 2018, 1561-1575).

\section{METHODS}

To compile the checklist, a database of previous and current grass collections from Isalo NP was compiled. Previous records of Isalo NP grass were downloaded from the Global Biology Information Facility (GBIF), which contains full data from herbarium specimens collected from the 18th century onwards and held in TAN and P (Rabarivola et al. 2019 a,b). Previous knowledge of the grasses of 
Isalo massif was also synthesized from Bosser (1969), Morat (1973), Swierkosz (2007), Vorontsova et al. (2016), MNP (2017) and Solofondranohatra et al. (2018).

Field inventories were made in March and April 2018 and new grass records were generated (Figure 1). As many different grasses as possible were collected and their presence was recorded in all accessible habitats of Isalo NP. For each species, herbarium, and DNA samples (leaf fragments) were collected to be conserved in herbaria of TAN, $\mathrm{P}$ and $\mathrm{K}$ in London. Herbarium specimens were
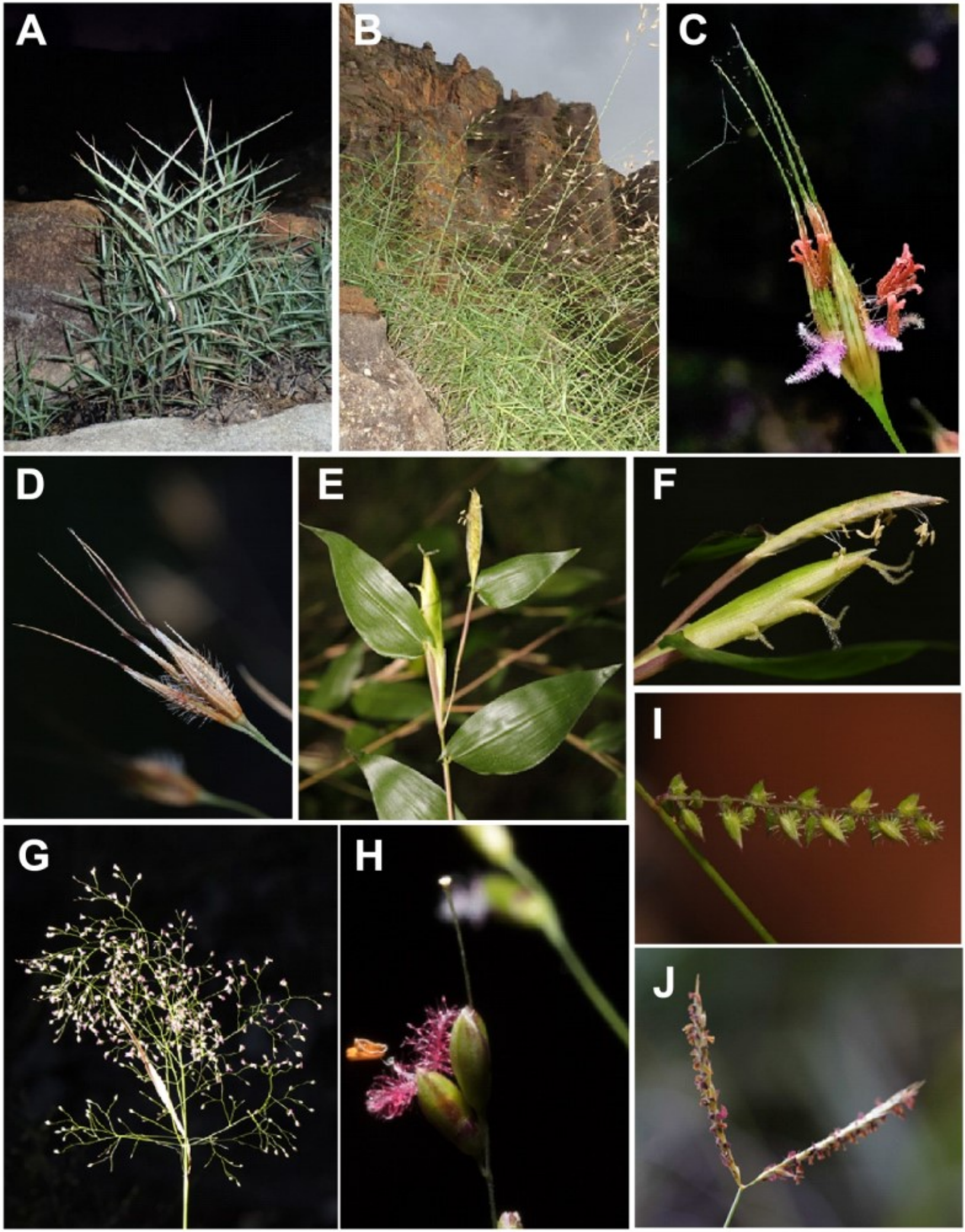

Figure 1. Madagascar endemic grasses found in Isalo massif. (A: Tristachya humbertii in vegetative state (Isalo NP, in April 2019); B: Tristachya (Isalus isalensis) in flower (Isalo NP, in April 2019); C: Flowering spikelets and D: mature spikelets of Tristachya (Isalus isalensis) (Isalo NP, March 2018); E: habit and F: inflorescence of Humbertochloa bambusiuscula (Isalo Sakamalio, March 2018); G: Inflorescence and H: spikelet of Panicum ibitense A.Camus (Isalo NP, March 2019); I: one raceme of Pseudechinolaena perrieri (Isalo Sakamalio, March 2018); J: digitate racemes of Andropogon eucomus Nees subsp. huillensis (Rendle) Sales (native to Madagascar) (Isalo NP, March 2018). Credit photo: David Rabehevitra (E, F, G, H \& I): Andotiana M. Andriamanohera (C): Nantenaina H. Rakotomalala (A, B, D \& J) 
identified using spikelet dissections (e.g., Figure 2), using existing herbarium specimens for comparison with our collections, and the identification keys available in Bosser (1969), Nanjarisoa et al. (2017) and Vorontsova et al. (2018).

The occurrence records were compiled in a single database using BRAHMS software (Botanical Research and Herbarium Management System) version 7. Species names and authorities were verified against the Plants of the World Online

(http://www.plantsoftheworldonline.org), whereas the global distribution of each species was obtained from the Madagascar Grass Atlas (Rabarivola et al. 2019d). Information on the photosynthetic system of each species was obtained from soreng et al. (2017). Data were exported from BRAHMS as a CSV file and analysed in MS Excel.

\section{RESULTS}

We assembled a total of 589 records of grasses from Isalo NP, representing 112 species. The list of species and the information on the collections and collectors of each species, the endemicity status, the type of ecosystems occupied, and the photosynthetic system are presented in Table 1 (see at the end of the document). Selected endemics and common native grasses are illustrated in Figures 1 and 2.

EXPLORATION HISTORY AND NEW LIST OF GRASSES OF ISALO NP. The collection of grasses in Isalo NP began in the 20th

century, but the real effort of documentation was expanded significantly by the mid-twentieth century. The first collection was made by Henri Perrier de La Bâthie in 1919, who recorded Aristida barbicollis Trin. \& Rupr. From this period, the number of collections

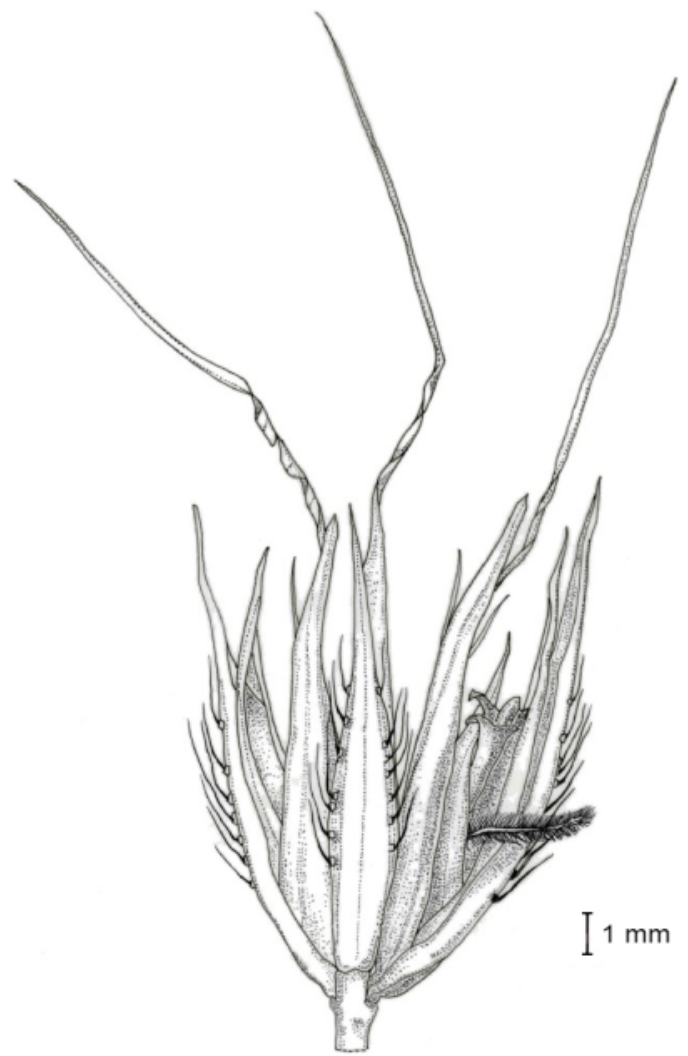

Figure 2. Line drawing of one triad of spikelets, 8-12 mm, on a branch of the panicle of Tristachya (Isalus isalensis). (Each spikelet is lanceolate and laterally compressed with bulbous-based trichomes on the nerves and twisted awns on the upper lemma. Drawing by Nantenaina Herizo Rakotomalala, from NHR 179, collected in Isalo NP on 27 April 2018) grew steadily and slowly, reaching $12 \%$ of the currently known grasses in Isalo NP by the end of 1950 (Figure 3). It was at this time that dedicated botanical investigation began in Isalo massif (Goodman et al. 2018, 1561-1575). Knowledge of grass species increased rapidly to reach $52 \%$ of the currently known species within the next two decades (1950-1970). Three collectors who recorded the most specimens and the most species in Isalo NP were part of this midtwentieth century documentation boom, namely: Jean Bosser (112 specimens, 39 species), Henri Humbert (46 specimens, 26 species) and Philippe Morat (28 specimens, 10 species). Grass collection almost ceased for a long period between 1970 and 2013. From 2013 onwards, one of the authors Maria Vorontsova and the Kew Madagascar Conservation Centre (KMCC) resumed the exploration of the diversity of grasses in Madagascar and in Isalo NP. Their collection efforts, combined with our own, significantly increase the number of grass species and specimens known from Isalo massif. Overall, 19 principal collectors with more than 30 co-collectors contributed to the current list of grass species in Isalo NP.

According to the available records, species have not been collected uniformly and only a few species are well enough sampled to give us an understanding of their distribution within the park. The most frequently recorded species was Loudetia simplex (Nees) C.E.Hubb. with 50 records. The next most frequently recorded species are Tristachya (Isalus isalensis (A.Camus) Phipps), Schizachyrium sanguineum (Retz.) Alston, and Craspedorhachis africana Benth., all collected over 30 times each. Many species were collected from Isalo NP only once (31 species) or twice (26 species).

There is a strong geographical bias in the grass collections carried out across the park (Figure 4). The southeastern part of Isalo NP is disproportionally well known because of its easy access and famous tourist landmarks, while the west and the north remain rarely or never explored. A minimum of one day drive followed by three days of walking are required to reach the northernmost part of Isalo NP. Our farthest expedition looking for grasses reached Sakamalio after one day's drive inside the park, followed by a day's walk to the campsite (blue stars in Figure 4). Access to Sakamalio was physically challenging and involved crossing a dense open grassland dominated by Heteropogon, Hyparrhenia, and Hyperthelia over $2 \mathrm{~m}$ tall and in fruit.

NEW GRASS RECORDS FOR ISALO NP. In this study, we worked to explore maximum spatial and habitat diversity across Isalo $\mathrm{NP}$, and to conduct a more thorough inventory in places where researchers had previously collected grasses. From our field expeditions in 2018, we collected a total of 178 specimens representing

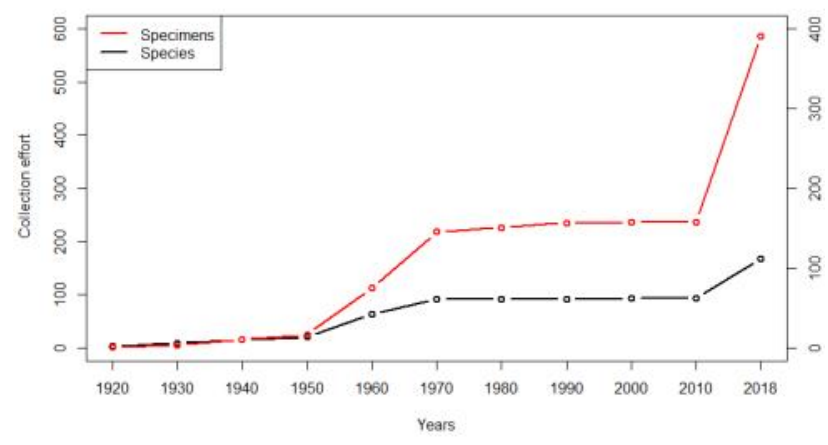

Figure 3. Cumulative number of Poaceae specimens and species collected in Isalo massif between 1919 and 2019. 


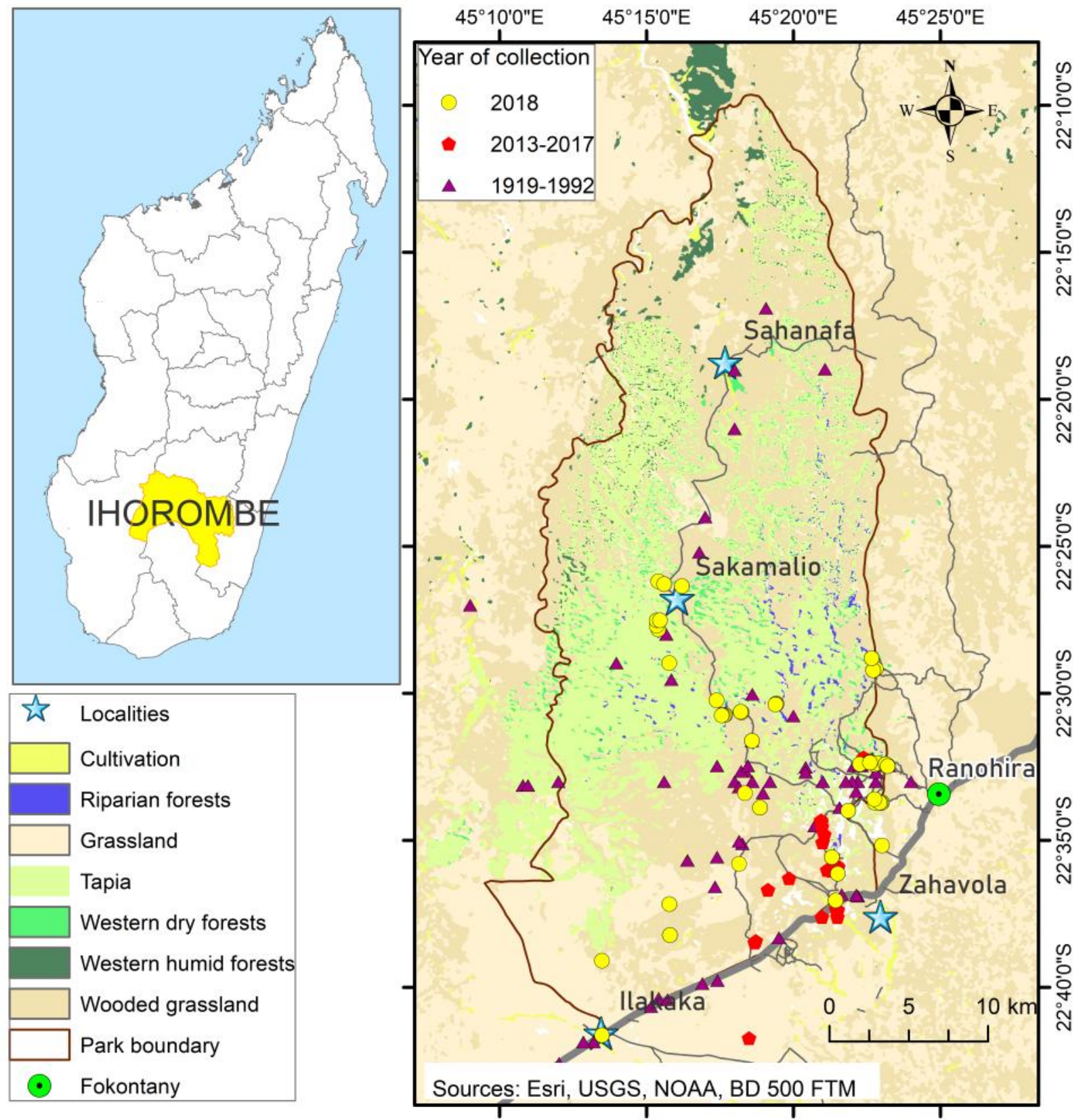

Figure 4. Location of Poaceae collection sites in the Isalo NP, all collections made in 1919-2018. (Collections made 1919-1999 in violet triangles, collection made 2013-2017 by M. S. Vorontsova in red polygons, and 2018 collections by N. Rakotomalala in yellow circles)

93 species, of which 38 were collected in Isalo NP for the first time (Table 1). Four of these new records document species endemic to Madagascar: Acroceras boivinii (Mez) A.Camus, Cyrtococcum deltoideum A.Camus, Humbertochloa bambusiuscula A.Camus \& Stapf. and Neostapfiella perrieri A.Camus (member of a Madagascar endemic genus). These 38 new occurrences were recorded both from rarely explored areas of Isalo NP and from the frequently visited ones. The new records we made in previously explored areas are generally represented either by tiny species that are difficult to notice (e.g., Aristida cumingiana Trin. \& Rupr.; Schizachyrium brevifolium (Sw.) Nees ex Büse), or by large species that are troublesome to collect (Neyraudia arundinacea (L.) Henrard; Rottboellia cochinchinensis (Lour.) Clayton), or by common weed species which collectors are likely to ignore (e.g., Chloris pycnothrix Trin., Eleusine indica Gaertn.). Most of these newly recorded species were previously known only in remote areas of Isalo massif, and of- ten ecologically different. Information on their previous distribution ranges is available in Rabarivola et al. (2019d). One of these new records, Neostapfiella perrieri, was found in a disturbed and trampled habitat in a single location along a frequented road: previously, this species was only known for the northwest and in the southernmost regions of Madagascar (Vorontsova and Rakotoarisoa 2014). In addition to the newly recorded grass species from Isalo $N P$, we made the third ever collection of a species endemic to Madagascar: Pseudechinolaena perrieri A. Camus in Sakamalio.

TAXONOMIC DIVERSITY OF ISALO'S POACEAE. The 112 known species in Isalo NP include three varieties and represent 59 genera and 16 tribes, according to the classification of Kellogg (2015). Of the 11 subfamilies present in Madagascar, seven are found in Isalo massif (Vorontsova et al. 2018). The tropical clade PACMAD (Panicoideae, Arundinoideae, Chloridoideae, Mi- 
crairoideae, Aristidoideae, and Danthonioideae) comprises most of the grasses in Isalo NP (109 species, 97\%). Panicoideae is the most dominant with 73 species (65\%), largely represented by the tribes Paniceae (45 species, 40\%) and Andropogoneae (19 species, 17\%), followed by Chloridoideae with 25 species (22\%). As for the temperate C3 clade BEP (Bambusoideae, Ehrhartoideae, Pooideae), it was represented by only one unidentified species of Bambusoideae and two species of the rice relatives Ehrhartoideae. The subfamily Pooideae, which is the most species-rich grass subfamily in the world and which is predominantly temperate (Kellogg 2015, Soreng et al. 2017), was not found in Isalo NP. At the generic level, Panicum sensu lato (morphologically similar but polyphyletic species historically called "Panicum" which have not yet been assigned to monophyletic groups, Vorontsova 2018) is the most diverse with 8 species, followed by Eragrostis sensu lato (including Pogonarthria, Soreng 2017) and Digitaria with 7 species, and by Sporobolus with 6 species. Of the 59 genera, 35 (60\%) are represented by a single species only. Species with the C4 photosynthetic system dominate with 91 species (81\%), suggesting a flora adapted to tropical open and seasonally dry habitats (Bond et al. 2008). The highest diversity in terms of species number has been recorded in the eastern part of the park, where not only most of the collections were made, but also where habitats are the most diverse: this is where the largest riparian forest and the only accessible canyon vegetation are found.

BIOGEOGRAPHIC AFFINITIES. The probable native origins of the grass species recorded from Isalo massif are shown in Figure 5. Three species and one variety (4\%) are endemic to Madagascar and restricted to the Isalo area: Styppeiochloa sp. nov. ined., Tristachya humbertii A.Camus, Tristachya (Isalus isalensis) and Pseudolasiacis neoperrieri (A.Camus) A.Camus var. leroyana Bosser \& Florens. Seven other endemic species (6\%) are restricted to the central highlands, and a further 12 endemic species (12\%) are widespread across the island (Table 1). Overall, 24 of the grass species of Isalo massif are endemic to Madagascar, with $22 \%$ endemicity, which is below the $40 \%$ grass endemicity for the country recorded by Vorontsova et al. (2016). Most of the grasses recorded in Isalo NP (81 species, 72\%) would be native to Madagascar and are also present in other parts of the world, predominantly in tropical Africa. Out of the 112 species, only seven (6\%) are thought to be introduced according to the literature survey by Kull et al. (2012), although the native versus introduced origin of many grasses remains unconfirmed. These possible aliens are: Cenchrus echinatus

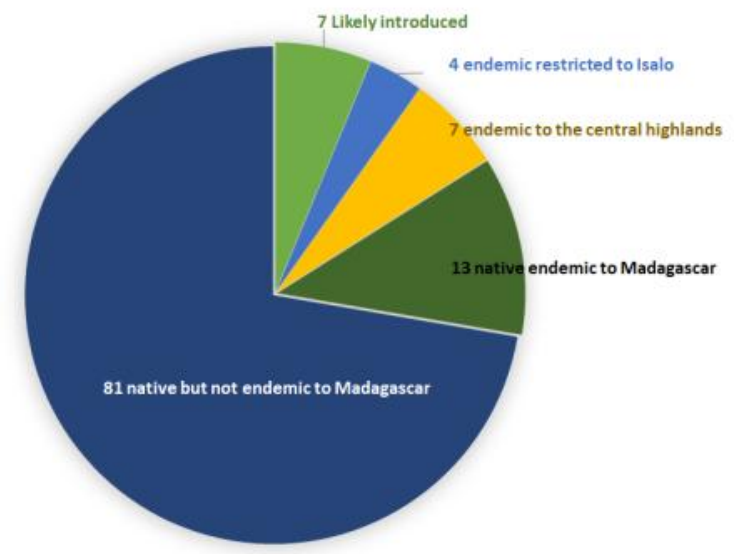

Figure 5. Distribution ranges and likely native/introduced status of the 112 grasses recorded in Isalo NP.
L., Cenchrus polystachios (L.) Morrone, Cenchrus purpureus (Schumach.) Morrone, Chloris virgata P.Durand, Digitaria violascens Link, Echinochloa colona (L.) Link, Enteropogon prieurii (Kunth) Clayton.

ENDEMIC GRASSES RESTRICTED TO ISALO MASSIF. Among the 112 grass species found in Isalo NP, three species and one variety are restricted to the area. One represents a new species: Styppeiochloa sp. nov., collected in 1940 and in 2013, and pending a revision of Styppeiochloa in Madagascar. Within the park, it was recorded in three locations associated with open and rocky environments. The other two species belong to the pantropical genus Tristachya. These are Tristachya humbertii and Tristachya (Isalus isalensis), previously assigned to the genus Isalus which has been subsumed within the genus Tristachya. They differ in habit and leaf morphology but have similar easily recognizable inflorescences: each inflorescence branch terminates in a cluster of 3 spikelets (Figures 1, 2). They often grow together, usually in open habitats on rocky substrates or under the Tapia canopy. As for the endemic variety Pseudolasiacis neoperrieri var. leroyana, revised by Bosser and Florens (1992), it was collected 6 times in riparian forest understory. It is a bamboo like liana plant that scrambles up into the wet forest canopy and is not immediately recognizable as a member of the Poaceae.

MYSTERIOUS BAMBOO. The population of arching long-necked pachymorph bamboo (bamboo terminology specifying the three-dimensional structure of its rhizomes which are narrow and short but belong to the clumping bamboo group, see vorontsova et al. 2018) growing around the Namaza stream is clearly a member of Madagascar's endemic bamboo radiation, subfamily Bambusoideae, tribe Bambuseae, subtribe Hickeliinae (Vorontsova et al. 2018). It was first collected by Vorontsova in 2013. The identity of this species is not yet well defined. It was initially erroneously identified as Valiha diffusa S.Dransf., the common arching bamboo of eastern and northern Madagascar. But phylogenetic analysis of its chloroplast markers shows that it is more closely affiliated with the poorly known western coast genus Perrierbambus (Hackel et al. 2018). However, the characters of its culm sheaths do not match this genus (Soejatmi Dransfiled, pers. comm.). It could be an undescribed genus. This species has not been known to flower, and the flowering time is unpredictable, as most bamboos.

SPECIES HABITATS. Grasses occur everywhere in Isalo NP, from open and arid (grassland, Tapia, roadsides, rock), to shady and/or damp areas (riparian forests, humid zones in canyons or marshes). Only the darkest understory of closed-canopy wet forest does not support Poaceae. The highest number of species was recorded in the grasslands (46 species) and in riparian forests (42 species) and the lowest on rocks (11 species) (Figure 6). Endemic species are present across all habitats with the highest number also recorded in grasslands and in riparian forests (Figure 6).

With the exception of Tristachya (Isalus isaloensis) and Urochloa maxima (Jacq.) R.D.Webster, which were found in almost all categorized habitats (see Table 1), Isalo massif grasses are usually restricted to specific habitats and environmental conditions. Grasses in arid and open habitats, i.e., grassland, Tapia, rock, and roadside, are represented mostly by Andropogoneae, Panicoideae and Chloridoideae. They are all C4, except the C3 Sartidia isaloensis Voronts., Razanatsoa \& Besnard, which grows on the exposed sandstone cliffs to benefit from the light and to avoid fire. These C4 


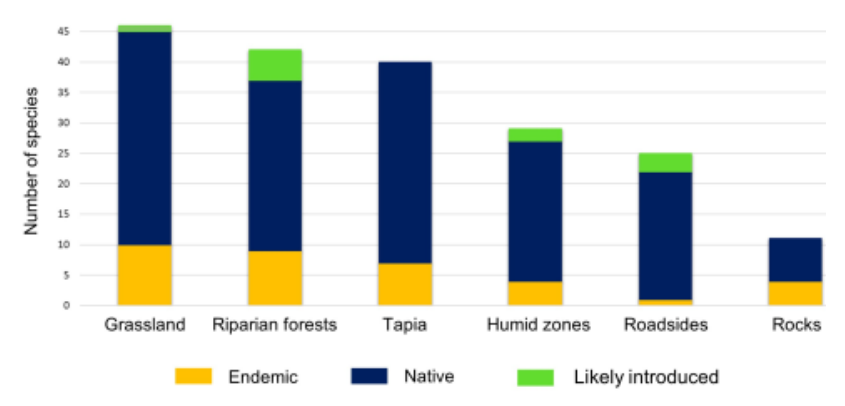

Figure 6. Distribution of species in the 6 available habitats in Isalo NP with proportion of native, likely introduced and endemic species in each habitat. (species numbers for each habitat were obtained from species distribution information in the project database and from field observation)

species are in general hemicryptophyte perennials, with tall, erect, and tufted habit, and coriaceous leaves which drive ground fires while not being damaged by them. These characters were shown by Solofondranohatra et al. $(2018,2020)$ to be an adaptation to fire, aridity, and light availability. This set of species is similar to the open arid and fire grasses of Itremo, which require prolonged exposure to sunlight and benefit from fires (Nanjarisoa et al. 2017). In damp and shady areas of Isalo NP (riparian forests and canyons), grasses are represented both by $\mathrm{C} 3$ and $\mathrm{C} 4$ species belonging mostly to Paniceae and to BEP clade. They generally have creeping habit with broad herbaceous leaves to adapt to limited light availability (Solofondranohatra et al. 2018). In the partially shaded understory of riparian forests of Isalo NP, the margins and gaps are dominated by shade-tolerant species: especially Oplismenus burmannii (Retz.) P.Beauv. and Panicum brevifolium D.Jahn ex Schrank. (Nanjarisoa et al. 2017). These species require permanent soil moisture and avoid sunlight. As for humid and riparian habitats, found in permanent or temporary marshes of Isalo NP, grasses are represented by species associated with prolonged inundation including especially Sacciolepis spp., Setaria sphacelata Stapf \& C.E.Hubb. ex M.B.Moss, and Echinochloa colona (L.) Link. These species form an ecological group associated with organic soils with high moisture that require high light exposure and at least a temporary immersion during their life cycle (Morat 1973).

ISALO AND ITREMO. The only other recent and comprehensive regional checklist of Madagascar grass is that of Itremo which is ca. $520 \mathrm{~km}$ north of Isalo NP, where 99 grass species have been recorded (Nanjarisoa et al. 2017). With an area of 24788 ha, Itremo is 3.5 smaller than Isalo NP and is also at a higher altitude (Table 2). Both areas are part of the central ecoregion with similar climatic conditions: Isalo NP is somewhat drier and warmer than Itremo, with a longer dry season. The grass flora of Isalo NP and Itremo are similar at subfamily, tribe, and genus levels. By calculating the similarities through Jaccard index, their subfamilies are $88 \%$ similar, tribes $65 \%$ similar, and genera $61 \%$ similar (see Appendix I, II). Fiftysix of the grass species of Isalo NP have also been recorded in Itremo. Except for the Pooideae, which are present in Itremo but not in Isalo NP, subfamilies are represented in similar proportions and both are dominated by the C4 major clades: Paniceae, Andropogoneae and Chloridoideae. The highest species diversity has also been recorded in the grasslands of both areas (Nanjarisoa et al. 2017). The total number of endemic grasses and the endemicity are higher in Itremo, despite the lower level of protection and greater human exploitation. Currently, compared to $22 \%$ of Isalo NP's grasses, $32 \%$ of Itremo's are endemic to Madagascar which likely reflects Itremo's higher elevation quartzite outcrops and its richer
Table 2. Comparison of the grass floras of Isalo and Itremo protected areas and their geographical and biological contexts. (Information about Itremo was obtained from Nanjarisoa et al. (2017) and from the Management Plan of the New Protected Area of Itremo (Ministère de l'Environnement et des Forêts 2012))

\begin{tabular}{lcc} 
& Isalo National Park & Itremo New Protected Area \\
\hline Surface area $(\mathrm{Ha})$ & 81540 & 24788 \\
Altitude $(\mathrm{m})$ & $541-1268$ & $1400-1700$ \\
Mean annual temperature $\left({ }^{\circ} \mathrm{C}\right)$ & 21 & 19.5 \\
Annual average rainfall $(\mathrm{mm})$ & $800-1200$ & $1000-1600$ \\
Wet season (months) & 4 to 5 & 7 to 8 \\
Main vegetation & Grassland, Tapia, Riparian & Grassland, Tapia, Riparian \\
& forests & forests \\
Total of species & 112 & 100 \\
Number of shared species & 56 & 56 \\
Total endemic & $24(22 \%)$ & $32(32 \%)$ \\
Number of local endemics & 4 & 2
\end{tabular}

Number of local endemics

adventitious and agriculture-associated flora (KMCC 2012). Isalo NP is however home to two more locally restricted endemic species than Itremo.

\section{DISCUSSION}

CHECKLIST. This study presents a list of grass species found in the Isalo NP: a total of 112 species, representing a tripling of the number of grasses reported by the Madagascar National Parks in Isalo NP in 2017 (MNP 2017).

Our results are broadly congruent with our expectations. Like the Itremo grass checklist, which increased the number of known grasses in the area threefold, this checklist brings the number of grass species of Isalo NP from 38 as cited by the MNP Ranohira in 2017 to 112 (MNP 2017). Our final species count is comparable to that of Itremo (Nanjarisoa et al. 2017), but significantly higher than that of the Andringitra National Park (18 species) (Lewis et al. 1996), and that of the forest reserve of Manongarivo (60 species) (Gautier 2002), possibly due to the lack of an attentive search for grasses in Andringitra and Manongarivo.

The checklist presented in this study was based on both historic and new herbarium specimens, which were identified via spikelet dissections and comparison with verified herbarium specimens. All collections were successfully identified except the 21 specimens where images were not available from the $P$ herbarium. A species checklist can never be fully complete without comprehensive and repeated field observations carried out over multiple field seasons and throughout the year, which were not practically possible within a time limited project like this one, especially as identification without flowering material remains largely impossible. We anticipate that further grass species are likely to be found flowering outside the wet season months of March - April when fieldwork for this study took place.

DIVERSITY AND ENDEMICITY. The highest diversity of Poaceae species was recorded in the vehicle-accessible eastern part of the Isalo park, where the diverse habitats created by forests and streams in deep canyons create a variety of niches separated by sandstone outcrops, allowing both the fire-dependent and fire-vulnerable C4 and C3 grasses to grow. But since this is the only area of the park that was well investigated, we still expect to uncover further diversity in the north and west of the park, where habitat diversity, canyons, and different forest types are also prominent. Other species-rich families also seem to be under-recorded in Isalo NP. For Fabaceae, only 42 of 592 of the total species in Madagascar were recorded from Isalo NP, and for the Asteraceae, only 21 of 516 species (Du Puy 2002, MNP 2017, Goodman et al. 2018, 1561-1575). Poaceae are the first large plant family present in Isalo NP that was fully inventoried via a specialist survey. The reasonable similarity of grass taxa found in Isalo NP and Itremo supports the assertion of Vorontsova et al. (2016) claiming that sites of the same ecoregion 
and of the same vegetation types are similar in terms of grass species composition.

Poaceae endemism is known to be geographically the lowest in the central highlands where grasslands are dominant, excluding high mountains (Bond et al. 2008). Preliminary lists of grasses in other ecoregions have already revealed higher levels of endemism compared to that Isalo NP, such as $97 \%$ (17 out of 18 species) in montane grasslands of Andringitra and 58\% (19 out of 33 species) in the montane region (Humbert 1955, Lewis et al. 1996, Vorontsova et al. 2016), although grass endemism there is likely inflated due to under-recording of common weedy species. However, grass checklists of Tanzanian protected areas record much lower endemism ranging from only 2 to $12 \%$ (Vollesen et al. 1999, Williams et al. 2016). These areas are an order of magnitude larger than Isalo NP but demonstrate even lower endemism. The level of endemism in the Madagascar's grass flora is well above the global average for large islands (Vorontsova et al. 2016), and that of Isalo NP is consistent with this expectation.

In spite of their discreet appearance, more than a hundred different grasses are found in Isalo NP, dominating and driving the function of its extended grasslands, and carpeting much of its forest understory. Isalo grasslands are mainly dominated by Loudetia simplex, Loudetia filifolia, Trachypogon spicatus, Chrysopogon serrulatus, and Schyzachyrium sanguineum. Isalo massif is part of the central highland grasslands, long assumed to be secondary biomes (e.g., Morat 1973, Koechlin et al. 1974), as they are considered species-poor with lower endemism compared to other ecoregions and other woody biomes (Morat 1973, Bond et al. 2008, Vorontsova et al. 2016). In Isalo NP, they are described by Gautier (2018) as "vast stretches of secondary grasslands and pastures" which "cover 40\% of the site". Morat (1973) judged the southwestern grasslands to be largely anthropogenic as they are species-poor, consisting of only a few endemic species and grassland species but apparentely with many ruderal and introduced species.

HISTORY OF ISALO'S GRASSLANDS AND PEOPLE. Environ-

mental changes and disturbances are indeed prevalent in many parts of the island, as Malagasy people have depended on forests and their destruction since their settlement probably around 1350-1100 y B.P. (Anderson et al. 2018). However, no history of change in vegetation cover has been recorded for the open canopy ecosystems of Isalo NP (e.g., Goodman 2018, 1561-1575). Their only documented human use is cattle grazing by the Bara people, which may not have significantly altered a naturally firedriven tropical grassy ecosystem (Zafisoalizy 2011). Instead, the Bara's historical activities seem likely to have maintained Isalo's ancient grasslands until the establishment of the Isalo NP in 1962. These cattle herders settled in Ranohira for its extended grasslands that could make good pasture (Rajaofera 2007, Zafisoalizy 2011). Their livelihoods were always more dependent on grassland and fire than on agriculture. They frequently burned grasslands but did not cut many trees (Rajaofera 2007, Zafisoalizy 2011). For construction, they built their houses out of clay and grass. Recent studies suggest that the Bara are indeed protectors of nature and forest, and they conserved trees because they believe that trees and forests create rain and because they use forests to hide their zebu from thieves (Zafisoalizy 2011, Saandi 2012). Comparatively few people occupy the immense territory of Ranohira. In 1945, the population density of this area was 0.3 inhabitants $/ \mathrm{km}^{2}$ (Gourou 1945).
TAPIA. Grasses make up the herbaceous layer of the Tapia ecosystems of the central highlands. These ecosystems are dominated by Uapaca bojeri trees, which are endemic to Madagascar (Kull 2003, Kull et al. 2005). Swierkosz (2007) called them sclerophyllous woodland and defined them as a lax formation with many gaps, where shrubs and herbaceous vegetation cooccur. This ecosystem was also previously classified as a "forest" (e.g., Rajeriarison \& Faramalala 1999), but a recent study has demonstrated it to be functionally a form of savana grassland (Solofondranohatra et al. 2018). Tree-less grasslands and Tapia are both fire-resistant and light-dependent, with an understory composed of similar grass species (Solofondranohatra et al. 2018). Their grass species are taxonomically and phylogenetically highly diverse, indicating that they have a long evolutionary history and should have been present in the region before human settlement (Solofondranohatra et al. 2018). During our survey, we also found a similar species composition in open-canopy grasslands and under Tapia (Table 1). This suggests that grasses and their functional traits have always been an integral part of these ecosystems.

Addressing the question of origin of grasslands (and distinguishing between grasslands of different ages) remains a challenge and must involve multi-disciplinary studies. However, our results are consistent with the presence of ancient grasslands in Isalo massif.

OTHER ORGANISMS IN ISALO GRASSLANDS. Grasslands are

home to a diversity of plants and animals, including those in Isalo massif. A diversity of ants, amphibians, reptiles and birds are found there (although not all are well documented), as well as restricted endemic species (e.g., Monotes madagascariensis trees, Mantella expectata frogs) (Mercurio et al. 2008, MNP 2017). Bond et al. (2008) hypothesized that the presence of endemic plants and animals in Madagascar's grasslands is consistent with a pre-human history. A natural open canopy grassland ecosystem would be expected to have associated dicotyledonous herbs, animals, and an invertebrate fauna (e.g., Bond and Parr 2010) and the lack of a specialised fauna has been cited as a sign of anthropogenic origin (Morat 1973). The absence of endemic amphibians and reptiles in the high plateau grasslands was used by Raxworthy and Nussbaum (1996) as evidence that the current grasslands are recent and artificial, and that the original vegetation and endemic herpetofauna must have been lost. Nevertheless, highland grassland ant assemblages are more diverse in Madagascar than forest ones (Fisher and Robertson 2002), and species diversity and distributions of local termites and other invertebrates remain incompletely documented. Fungi and microorganisms need study.

ISALO COMPARED TO OTHER PARTS OF MADAGASCAR AND THE REST OF THE WORLD. Isalo massif is part of the central and western grasslands, which represent $70 \%$ of the Madagascar's grassy ecosystems (Faramalala 1988). In Madagascar, grasslands have probably formed during the Miocene as part of their global expansion (Strömberg 2011), which is congruent with the similarity between the diversity of C4 grass lineages in Madagascar and Africa (Bond et al. 2008) and with the dating of Malagasy endemic C4 grass clades to around 1-6 Ma (Hackel et al. 2018). Rather than starting to expand from one region, grasses and grasslands likely already existed in many parts of Madagascar, generating high spatial and ecological turnover in the flora across the island (Vorontsova et al. 2016). Eighty one percent of Isalo's grasses 
are $\mathrm{C} 4,15$ of these endemic and the rest belonging to common African genera. Moreover, the grass flora of Isalo NP demonstrates some affinity with that of Itremo, as they belong to the same ecoregion, but has also its own specificity, especially when compared with other sites in different ecoregions. The C4 grasses of Isalo massif and their ancestors are therefore likely to have been part of the global diversification of Miocene grass and grass-dominated ecosystems, as grassland already existed in this area before human arrival. Fire and grazing regimes prior to human arrival in the area are likely to have maintained these grasslands even where climatic conditions can support forest (Solofondranohatra et al. 2020). However, we cannot ignore the fact that human activities are also leading to a significant expansion of grasslands in Madagascar, and the inherently dynamic nature of grassy ecosystems makes it difficult to infer the exact history of any single specific location with any level of confidence. Understanding the history of Madagascar's grasslands is a complex task and requires more detailed ecological, genetic, and soil science studies.

CONSERVATION. The recent tree-planting programs in

Madagascar highlight the need for clearer conservation policy for the island's grassy ecosystems that may have a pre-human origin and could suffer irreversible damage from the introductions of pine and eucalypt trees. It has been shown that some of the world's ancient grasslands hold more carbon under the ground than plantation forests in the same area (Gibson 2009), as the roots of water-hungry trees dry out the deep grassland soils, causing aerobic decomposition of carbon-rich soils. There is hence an urgent need for further research on grassy ecosystems such as those of the Isalo NP, preferably by delineating pre-human versus post-human grassy ecosystems, in order to avoid this damage from exotic tree planting in grasslands.

\section{CONCLUDING REMARK}

We hope this work contributes to the growing body of knowledge of Madagascar's grasses as a beautiful and diverse, as well as ecologically significant component of Madagascar's botanical wealth. We invite all biologists working in Madagascar to notice the Poaceae and make collections of these amazing plants to build this knowledge together, and we are happy to assist colleagues with learning to identify grasses. We also hope to promote the study of open canopy ecosystems in order to redress the historical focus on wet forest to the exclusion of other ecosystems.

\section{ACKNOWLEDGEMENTS}

This research was funded by an Emily Holmes Memorial Fellowship awarded to Nantenaina Herizo Rakotomalala, and by the Millennium Seedbank Partnership which supported field work. It is a collaboration between the Department of Plant Biology and Ecology of the University of Antananarivo (DBEV) and the Kew Madagascar Conservation Center (KMCC). The authors would like to thank Stuart Cable (RBG Kew), and everyone at KMCC for supporting this work. Special thanks to Yvon Tovondrainy and Noël Randrianasolo (Madagascar National Parks, Ranohira) for their field assistance, to the Direction Générale des Forêts (DGF) for granting research permits, and to the Parc Botanique et Zoologique de Tsimbazaza (PBZT) for supporting permit applications, as well as to the curators of the $\mathrm{K}, \mathrm{P}$ and TAN herbaria for providing access to specimens and the microscope.

\section{REFERENCES}

Anderson, A., Clark, G., Haberle, S., Higham, T., Nowak-Kemp, M., Prendergast, A., et al. 2018. New evidence of megafaunal bone damage indicates late colonization of Madagascar. PLOS ONE 13: e0204368. <http://dx.doi.org/10.1371/journal.pone.0204368>

Barkworth, M. E., Capels, K. M., Long, S. and Piep, M. P. 2003. Flora of North America North of Mexico. Volume 25, Magnoliophyta: Commelinidae (in part). Poaceae. Part 2. Oxford University Press, New York.

Barkworth, M. E., Capels, K. M., Long, S., Anderton, L. K. and Piep, M. P. 2007. Flora of North America North of Mexico. Volume 24, Magnoliophyta: Commelinidae (in part). Poaceae. Part 1. Oxford University Press, New York.

Bond, W. J. and Parr, C. L. 2010. Beyond the forest edge: ecology, diversity and conservation of the grassy biomes. Biological Conservation 143, 10: 2395-2404. <https://doi.org/10.1016/j.biocon.2009.12.012>

Bond, W. J., Silander, J. A., Ranaivonasy, J. and Ratsirarson, J. 2008. The antiquity of Madagascar's grassland and the rise of C4 grassy biomes. Journal of Biogeography 35, 10: 1743-1758. <https://doi.org/10.1111/j.13652699.2008.01923.x>

Bosser, J. 1969. Graminées des pâturages et des cultures. O.R.S.T.O.M. Paris.

Bosser, J. \& Florens, D. 1999. Pseudolasiacis (A. Camus) A. Camus (Poaceae) à Madagascar, aux Comores et aux Mascareignes. Adansonia 21, 2: 231-237. $<$ https://sciencepress.mnhn.fr/en/periodiques/adansonia/21/2/pseudolasiacis-camus-camus-poaceae-madagascar-aux-comores-et-aux-mascareignes>

Bouchenak-Khelladi, Y., Verboom, G. A., Savolainen, V. and Hodkinson, T. R. 2010. Biogeography of the grasses (Poaceae): a phylogenetic approach to revea evolutionary history in geographical space and geological time. Botanical Journal of the Linnean Society 162: 543-557. <https://doi.org/10.1111/j.10958339.2010.01041.x>

Burney, D. A. 1987. Late Quaternary stratigraphic charcoal records from Madagascar. Quaternary Research 28, 2: 274-280. <https://doi.org/10.1016/00335894(87)90065-2>

Burney, D. A. 1997. Theories and facts regarding Holocene environmental change before and after human colonization. In: Natural change and human impact in Madagascar. S. M. Goodman and B. D. Patterson (eds.), pp 75-89. Smithsonian Institution Press, Washington D. C.

Convey, P. 2001. Antarctic ecosystems. In: Encyclopedia of Biodiversity. Levin S.A. (ed.), pp 171-184. Academic Press, San Diego.

Davidse, G., Sousa, S. M. and Chater, A. 1994. Flora Mesoamericana 6: Alismataceae to Cyperaceae. UNAM, Mexico City, México.

Du Puy, D. and Moat, J. 1996. A refined classification of the primary vegetation of Madagascar based on the underlying geology: using GIS to map its distribution and to assess its conservation status. In: Biogéographie de Madagascar. W.R. Lourenço (ed.), pp 205-218. ORSTOM, Paris.

Du Puy, D. J. 2002. Introduction. In: The Leguminosae of Madagascar. D. J. Du Puy, J.N. Labat, R. Rabevohitra, J.-F. Villiers, J. Bosser and J. Moat (eds.), pp 1-8. Royal Botanic Gardens, Kew, London.

Faramalala, M. H. 1988. Étude de la Végétation de Madagascar à l'aide des Données Spatiales. Université Paul Sabatier, Toulouse, France.

Fisher, B. L. and Robertson, H. G. 2002. Comparison and origin of forest and grassland ant assemblages in the High Plateau of Madagascar (Hymenoptera: Formicidae) 1. Biotropica 34, 1: 155-167. <https://doi.org/10.1111/j.17447429.2002.tb00251.x>

Gasse, F. and Van Campo, E. 1998. A 40,000-yr pollen and diatom record for Lake Tritrivakely, Madagascar, in the southern tropics. Quaternary Research 49: 299 311. <https://doi.org/10.1006/qres.1998.1967>

Gautier, L. 2002. Liste commentée des phanérogames de la Réserve Spéciale de Manongarivo, Madagascar. Boissiera 59: 105-239. Available online <http:// www.ville-ge.ch/cjb/publications/cand0611/candollea61-1_51-60.pdf>

Gautier, L., Tahinarivony, J. A., Ranirison, P. and Wohlhauser, S. 2018. Vegetation. In: Les Aires Protégées Terrestres de Madagascar: Leur histoire, Description et Biote / The Terrestrial Protected Areas of Madagascar: Their History, Description, and Biota, S. M. Goodman, M. J. Raherilalao and S. Wohlhauser (eds.), chapter 7, pp 207-242. Association Vahatra, Antananarivo.

Gibson, D. J. 2009. Grasses and Grassland Ecology. Oxford University Press, Oxford. Available online <https://doi.org/10.2989/10220111003703542> 
Goodman, S. M., Raherilalao, M. J. and Wohlhauser, S. 2018. Site 90. Isalo. In: The Terrestrial Protected Areas of Madagascar: Their History, Description, and Biota, volume III. S. M. Goodman, M. J. Raherilalao and S. Wohlhauser (eds.), pp 15611575. Association Vahatra, Antananarivo.

Gourou, P. 1945. La population de Madagascar. Annales de Géographie 54, 296: 299301. Librairie Armand Colin, Paris. <https://doi.org/10.3406/geo.1945.12766>

GPWG (Grass Phylogeny Working Group). 2001. Phylogeny and subfamilial classification of the grasses (Poaceae). Annals Missouri Botanical Garden 88, 3: 373 457. <https://doi.org/10.2307/3298585>

Hackel, J., Vorontsova, M. S., Nanjarisoa, O. P., Hall, R. C., Razanatsoa, J., et al. 2018. Grass diversification in Madagascar: in situ radiation of two large C3 shade clades and support for a Miocene to Pliocene origin of $\mathrm{C} 4$ grassy biomes. Journal of Biogeography 45, 4: 750-761. <https://doi.org/10.1111/jbi.13147>

Humbert, H. 1955. Les territoires phytogéographiques de Madagascar. Année Biologique 31, 5-6: 439-448.

INSTAT Madagascar. 2020. Troisième Recensement Général de la Population et de I'Habitation (RGPH-3). Available online <https://www.instat.mg/wp-content/ uploads/Resultat-globaux-RGPH3-Tome-01.pdf $><$ https://www.instat.mg/wpcontent/uploads/Resultat-globaux-RGPH3-Tome-02.pdf>

Kellogg, E. A. 2015. XIII Flowering plants. Monocots: Poaceae (Vol. 13). In: The Families and Genera of Vascular Plants. K. Kubitzki (ed.). Springer.

KMCC. 2012. Plan d'Aménagement et de Gestion de la Nouvelle Aire Protégée du massif d'Itremo-Ambatofinandrahana Région Amoron'I Mania. Madagascar. Antananarivo.

Koechlin, J., Guillaumet J. L. and Morat, P. 1974. Flore et Végétation de Madagascar. A.R.G. Gantner Verlag, FL 9490 Vaduz. Available online <http://www.documentation.ird.fr/hor/fdi:010007501>

Kull, C. A. 2003. Uapaca woodlands. In: The Natural History of Madagascar. S. M. Goodman and J. P. Benstead (eds), pp 393-398. The University of Chicago Press, Chicago.

Kull, C. A., Ratsirarson J. and Randriamboavonjy, G. 2005. Les forêts de Tapia des Hautes Terres malgaches. Terre Malgache 24, 2: 22-58. Available online <http://madarevues.recherches.gov.mg/IMG/pdf/terre-mg24_2_-2.pdf>

Kull, C. A., Tassin, J., Moreau, S., Rakoto Ramiarantsoa, H., Blanc-Pamard, C. and Carrière, S. M. 2012. The introduced flora of Madagascar. Biological Invasions 14 4: 875-888. <https://doi.org/10.1007/s10530-011-0124-6>

Lewis, B. A., Phillipson, P. B., Andrianarisata, M., Rahajasoa, G., Rakotomalaza, P. J., et al. 1996. A study of the botanical structure, composition and diversity of the eastern slopes of the Réserve Naturelle Intégrale d'Andringitra, Madagascar. Fieldiana 85: 24-75. Entire volume available online <https://doi.org/10.5962/ bhl.title.3458>

Mercurio, V., Aprea, G., Crottini, A., Mattioli, F., Randrianirina, J. E., et al. 2008. The amphibians of Isalo Massif, southern-central Madagascar: high frog diversity in an apparently hostile dry habitat. In: A Conservation Strategy for the Amphibians of Madagascar. Monographie XLV. Andreone F. and Randriamahazo H. (eds.), pp 143-196. Museo Regionale di Scienze Naturali, Torino. Available online <https://www.researchgate.net/publication/237378170_The_amphibianS_of_Isalo_Massif_southern-central_Madagascar_High_frog_diversity_in_an apparently_hostile_dry_habitat>

Moat, J. and Smith, P. 2007. Atlas of the Vegetation of Madagascar. Royal Botanic Gardens, Kew. London. Available online <https://www.researchgate.net/publication/312443439_Atlas_of_the_vegetation_of_madagascar $><$ https:// kew.iro.bl.uk/work/22ee6576-f4c2-4fa8-a2b9-843f473bcfaf>

Morat, P. 1973. Les Savanes du Sud-Ouest de Madagascar (No. 68).ORSTOM, Paris.

Myers, N., Mittermeier, R.A., Mittermeier, C.G., Da Fonseca, G.A.B. and Kent, J. 2000 Biodiversity Hotspots for conservation priorities. Nature 403: 853-858. $<$ https://doi.org/10.1038/35002501>

Nanjarisoa, O. P., Besnard, G., Ralimanana, H., Jeannoda, V and Vorontsova, M. S. 2017. Grass survey of the Itremo Massif records endemic central highland grasses. Madagascar Conservation \& Development 12, 1: 34-40. <https:// doi.org/10.4314/mcd.v12i1.6>

Rabarivola, M. L., Vorontsova, M., Razanajatovo, H., Razafiniary, V. and Ralimanana, H. 2019a. All herbarium specimens of grasses from Madagascar and the surrounding islands: family Poaceae, sector AFM. Version 1.24. Kew Madagascar Conservation Centre - Royal Botanic Gardens Kew. Occurrence dataset accessed via GBIF.org on 2 Nov. 2019 <https://doi.org/10.15468/51pabx>
Rabarivola, M. L., Razafiniary, V., Razanajatovo, H., Rapanarivo, S. H., Ralimanana, H., and Vorontsova, M. 2019b. All herbarium specimens of grasses held at TAN herbarium. Version 1.8. Kew Madagascar Conservation Centre - Royal Botanic Gardens Kew. Occurrence dataset accessed via GBIF.org on 2 Nov. 2019 <https://doi.org/10.15468/v6mfx2>

Rabarivola, M. L., Razanajatovo, H., Razafiniary, V., Ralimanana, H. and Vorontsova, M. 2019C. Research database of Madagascar grasses compiled by Maria Vorontsova. Version 1.3. Kew Madagascar Conservation Centre - Royal Botanic Gardens Kew. Occurrence dataset accessed via GBIF.org on 2 Nov. $<$ https://doi.org/10.15468/umduhk>

Rabarivola, M. L., Razanajatovo, H., Razafiniary, V., Rasolohery, A., Ralimanana, H. and Vorontsova, M. 2019d. Madagascar Grass Atlas. Kew Madagascar Conservation Centre, Madagascar.

Rajaofera, C. 2007. Contribution à I'histoire des Zafimanely, I'exemple du royaume Barabe, de sa création au début de la période coloniale. Formation Doctorale Multidisciplinaire. Université de Toliara, Madagascar. <http://biblio.univ-antananarivo.mg/pdfs/rajaoferaChristophe_FR_M2_07.pdf>

Rajeriarison, C. \& Faramalala, M. H. 1999. Nomenclature des Formations Végétales de Madagascar. ANGAP, Antananarivo.

Rakotoarimanana, V. 2008. Feu, pâturage et dynamique des savanes à Madagascar Habilitation à Diriger des Recherches en Biologie et Ecologie Végétale. Unpubl. Ph. D. thesis, Université Antananarivo, Madagascar.

Raxworthy, C. J. and Nussbaum, R. A. 1996. Amphibians and reptiles of the Réserve Naturelle Intégrale d'Andringitra, Madagascar: a study of elevational distribution and local endemicity. In: A floral and faunal inventory of the eastern slopes of the Réserve Naturelle Intégrale d'Andringitra, Madagascar: with reference to elevational variation. S. M. Goodman (ed), pp 158-170. Field Museum of Natural History, Chicago.

Saandi, Y. M. 2012. Dynamique de gestion des ressources naturelles dans le sudouest malgache : cas du Parc National Zombitse Vohibasia et ses zones périphériques. Diplôme d'Études Approfondies. Université de Toliara, Madagascar. <http://biblio.univ-antananarivo.mg/pdfs/ saandiYousoufM_GEO_DNR_12.pdf>

Solofondranohatra, C., Vorontsova, M. S., Hackel, J., Besnard, G., Cable, S., Jeannoda V., and Lehmann, C. E. R. 2018. Grass functional traits differentiate forest and savannah in the Madagascar central highlands. Frontiers on Ecology and Evolution 6: \#184. <https://doi.org/10.3389/fevo.2018.00184>

Solofondranohatra, C. L., Vorontsova, M. S., Hempson, G. P., Hackel, J., Cable, S., Jeannoda Vololoniaina, J. \& Lehmann, C. E. R. 2020. Fire and grazing determined grasslands of central Madagascar represent ancient assemblages. Proceedings of the Royal Society B 287, 1927: 20200598. <https://doi.org/ 10.1098/rspb.2020.0598>

Soreng, R. J., Peterson, P. M., Romashenko, K., Davidse, G., Zuloaga, F. O., et al. 2015 A worldwide phylogenetic classification of the Poaceae (Gramineae). Journa of Systematics and Evolution 53, 2: 117-137. <https://doi.org/10.1111/ jse.12150>

Soreng, R. J., Peterson, P. M., Romashenko, K., Davidse, G., Teisher, J. K., Clark, L. G., Berbera, P., et al. 2017. A worldwide phylogenetic classification of the Poaceae (Gramineae) II: An update and a comparison of two 2015 classifications. Journal of Systematics and Evolution 55, 4: 259-290. <https://doi.org/ 10.1111/jse.12262>

Strömberg, C. A. E. 2011. Evolution of grasses and grassland ecosystems. Annual Review of Earth and Planetary Sciences 39: 517-544. <https://doi.org/ 10.1146/annurev-earth-040809-152402>

Swierkosz, K. 2007. Vegetation of the southern part of the Isalo Sandstone Massif (Central Madagascar, Africa) - differentiation and threats. In: Sandstone Landscapes. P. Migón and M. Kasprzak (eds), pp 158-160. Museum of Natural History, Poland. <https://doi.org/10.6084/m9.figshare.92596>

Vieilledent, G., Grinand, C., Rakotomalala, F. A., Ranaivosoa, R., Rakotoarijaona, J. R., Allnutt, T. F. and Achard, F. 2018. Combining global tree cover loss data with historical national forest cover maps to look at six decades of deforestation and forest fragmentation in Madagascar. Biological Conservation 222: 189197. <https://doi.org/10.1016/j.biocon.2018.04.008>

Vollesen, K., Abdallah, R., Coe, M. and Mboya, E. 1999. Checklist: vascular plants and pteridophytes of Mkomazi. In: The Ecology, Biodiversity and Conservation of a Tanzanian Savanna. Mkomazi (ed.), pp 81-116. Royal Geographical Society, London. 
Vorontsova, M. S. 2018. Revision of the group previously known as Panicum L. (Poaceae: Panicoideae) in Madagascar. Candollea 73, 2: 143-186. <https:// doi.org/10.15553/c2018v732a1>

Vorontsova, M. S. and Rakotoarisoa S. E. 2014. Endemic non-bambusoid genera of grasses (Poaceae) in Madagascar: Review of current knowledge. Malagasy Nature 8: 14-34. Available online <http://www.vahatra.mg/volume8/ mn08_chapter02.pdf>

Vorontsova, M. S., Clayton, D. and Simone, B. K.. 2015. Grassroots e-floras in the Poaceae: growing GrassBase and Grass World. PhytoKeys 48: 73-84. <https:// doi.org/10.3897/phytoeys.48.7159>

Vorontsova, M. S., Besnard, G., Forest, F., Malakasi, P., Moat, J., Clayton, W. D., et al. 2016. Madagascar's grasses and grasslands: anthropogenic or natural? Proceedings of the Royal Society B: Biological Sciences 283, 1823: 20152. <https://doi.org/10.1098/rspb.2015.2262>

Vorontsova, M. S., Dransfield, S., Renvoize, S., Besnard, G., McRobb, A., Razanatsoa, J. and Ralimanana, H. 2018. Identification Guide to Grasses and Bamboos in Madagascar. Royal Botanic Gardens, Kew.

Vorontsova, M. S, Lowry II, P. P, Andriambololonera, S. R, Wilmé, L., Rasolohery, A., Govaerts, R., Ficinski, S. Z. and Humphreys, A. M. 2021. Inequality in plant diversity knowledge and unrecorded plant extinctions: an example from the grasses of Madagascar. Plants People Planet 3, 1: 45-60. <https://doi.org/ 10.1002/ppp3.10123>

Williams, E., Ntandu, J. E., Ficinski, S. and Vorontsova, M. S. 2016. Checklist of Serengeti Ecosystem Grasses. Biodiversity Data Journal 4: e8286. <https:// doi.org/10.3897/BDJ.4.e8286>

Zafisoalizy, M. 2011. La société Bara et les feux de brousses (L'exemple du district de Sakaraha). Diplôme d'Études Approfondies de Sciences Sociales. Université de Toliara, Madagascar. <http://biblio.univ-antananarivo.mg/pdfs/ zafisoalizyMonica_GEO_M2_11.pdf>

\section{SUPPLEMENTARY MATERIAL}

Appendix I: Comparison of grasses recorded by dedicated grass checklist projects in Isalo NP (this study) and in Itremo (Nanjarisoa et al. 2017). (Taxa marked in pink are unique to Isalo massif, and those in green to Itremo)

Appendix II: The numbers of grass subfamilies, tribes, genera, and species found in Itremo and in Isalo protected areas and listed in Appendix I, followed by the number present in both areas. Jaccard (Sj) similarity indexes were calculated as follows: Shared taxa between Isalo and Itremo/(Total for Isalo + Total in Itremo - Shared species).

Madagascar National Parks (MNP). 2017. Plan d'aménagement et de Gestion. Plan quinquennal de mise en œuvre 2017-2021 : Parc National d'Isalo. Régions Ihorombe et Atsimo Andrefana. Madagascar. Antananarivo. 